\title{
Development and Assessment of a Direct Evaporative Cooling Facility for Storing Fruit and Vegetables
}

\author{
Olunloyo O.O. ${ }^{1}$, Olunloyo A.A. ${ }^{2}$, Ibiyeye D.E. ${ }^{3}$ \\ ${ }^{1}$ Lecturer II, Department of Crop Production Technology, Federal College of Forestry, \\ Ibadan, Nigeria \\ ${ }^{2}$ Lecturer I, Department of Agricultural Technology, Federal College of Forestry, Ibadan, Nigeria \\ ${ }^{3}$ Lecturer II, Department of Crop Production Technology, Federal College of Forestry, \\ Ibadan, Nigeria
}

\begin{abstract}
This paper discusses the design, construction and assessment of a modified, cost-effective evaporative cooling facility for the preservation of fresh fruits and vegetables for use by the average Nigerian farmer, agri-business entrepreneur or layman. The designed facility makes use of cooling pads and constantly running water. It was designed and constructed with carefully selected inexpensive and readily available materials. The structure was made of internally and externally cemented sliced cement blocks. River sand was used as the cooling pad and product storage values were compared with those stored under ambient air conditions. Tomatoes were the test crop used to assess the structure's cooling efficiency. Findings showed that a cooling chamber filled with river sand as a cooling pad with constant application of water performed better in the storage of tomato fruit (Lycopersicum esculentum) than fruits stored under ambient conditions. It was therefore recommended that tomatoes should be stored under temperatures between $22-23^{\circ} \mathrm{C}$ to increase shelf life and reduce spoilage. There is a need for more work to be done in terms of introduction of fans, other cooling pad materials and constant water to enhance the structure's performance.
\end{abstract}

Key words: Storage, Evaporative cooling, Agricultural produce, Engineering, Crop production.

\subsection{INTRODUCTION}

Fruits and vegetables are vital agricultural produce for human consumption worldwide. They are rich in vitamins and minerals such as carotene (pro-vitamin A), Ascorbic acid, Riboflavin, Iron, Iodine, Calcium etc. [3]. However, most fruits and vegetables are not only seasonal, they are highly perishable. Producers suffer huge economic losses due to inadequate and inefficient storage methods [2]. Storage is of great importance because not all the harvested vegetables or crops in general may be used immediately after harvest. Some methods of preservation of fruits and vegetables include storage in ventilated sheds, at low temperatures, use of evaporative cooling systems, waxing and chemical treatment amongst others [7]. The bulk of post-harvest loss of fruits and vegetables in developing countries is due to the lack of proper storage facilities. Refrigerated cool stores are the best method of preserving fruits and vegetables but they are expensive to buy and run [6]. There is therefore an interest in simple low-cost, low power alternatives by developing countries [8].

Cold storage is defined as the storage of perishable food, furs, etc. in an artificially cold environment [8]. Cold storage extends the shelf life and the marketing of fruits and vegetables, avoiding food glut, and reducing transport bottle necks during the peak period of production. It therefore aids the control and minimization of spoilage and integrates cold chain network from the point of harvest to the point of purchase [5].

Evaporative cooling is a physical phenomenon in which evaporation of a liquid, typically into surrounding air, cools an object or a liquid in contact with it. It occurs when air that is not too humid passes over a wet surface; the faster the rate of evaporation the greater the cooling. Evaporative systems take advantage of the reduction in temperature resulting from the evaporation of mostly water to air [4].

Different types of evaporative coolers have been designed over time utilizing the direct or indirect evaporative cooling techniques. Evaporative cooling has been found to be useful for short term, on-farm storage of fruits and vegetables in hot and dry areas. 
Direct cooling systems involve the evaporation of water into the air to be cooled, simultaneously humidifying the air. Indirect cooling uses an air to air heat exchanger to remove heat from the primary air stream without adding moisture [1].

\subsection{METHODOLOGY}

The following steps were carried out in the development of the evaporative cooler:

\section{1 . Evaporative cooler design}

Evaporative cooling facility design consideration

The following factors were considered in the design of the evaporative cooling facility.

\subsubsection{Material selection:}

Since the design is to help local farmers and to reduce the cost of storage devices, the materials used were sourced locally and at the cheapest price available. They were selected on the basis of availability, cost, and durability amongst others.

\subsection{Dimensions:}

Each storage chamber has dimensions of $74 \mathrm{~cm} \times 24 \mathrm{~cm}$ and a depth of $40 \mathrm{~cm}$. The total volume of the evaporative cooler is $1.72 \mathrm{~m} 3$ and the designed structure can store $206.83 \mathrm{~kg}$ of tomatoes.

\subsection{Development of evaporative cooler}

The foundation of the rectangular shaped cooling structure was built from a single layer of boulders covered with sand, and then a cavity wall was constructed using six inch (6') hollow cement blocks around the outer edge of the floor with a gap of $12 \mathrm{~cm}$ between the inner and outer walls. The inner part was partitioned into 4 smaller chambers. River sand was used to fill the cavities. Palm fronds and bamboo were used to construct a shed for the cooling chamber to enhance effective cooling. A thermometer was placed in each chamber to determine the temperature. Planks were used to cover the chamber. They were perforated at the top and covered with net to avoid contamination and allow air to move in and out of the chamber. No load test was carried out on the structure before loading it with the test fruit (tomatoes). Tomatoes were stored in the chamber and the river sand was watered thrice daily.

\subsection{Assessment Of The Structure}

The structure was assessed using tomatoes as a test crop. The following parameters were assessed:

Temperature, Relative Humidity, weight, firmness and Colour.

1. Weight: was taken every two days to determine weight loss with the use of Camry high precision electronic scale (ISO9001:2008 Certified by SGS).

2. Temperature: Wet bulb and dry bulb temperatures were taken five times in a day (7am, 10am, 1pm, 4pm, 7pm) with a wet bulb and dry bulb thermometer at 3 hours interval to monitor and to determine the temperature of the chamber.

3. Relative Humidity: Atmospheric relative humidity was determined by the use of psychometric chart.

4. Cooling efficiency (for load test): indicates the extent to which the dry bulb temperature of the cooled air approaches the wet bulb temperature of the ambient air and was calculated using:

$\tau={\underline{\mathrm{Ta}}-\mathrm{T}_{1}}_{1} \times 100 \%$

Ta-Twb

where, $\mathrm{Ta}=$ Ambient air dry bulb temperature

$\mathrm{T} 1=$ Cooled air dry bulb temperature

$\mathrm{Twb}=$ Ambient air wet bulb temperature 
5. Physiological weight loss: The change in the weight of samples stored in the cooler and under ambient conditions was determined every two days. This was done for a total of nine days of the test period after which the percentage weight was estimated using the formula below:

Percentage weight $=\underline{\text { Original weight }- \text { New weight } \times 100}$

Original weight

Where $\% \mathrm{~W}=$ Percentage weight

$\mathrm{Wi}=$ Original weight

$\mathrm{Wn}=$ New weight

\subsection{RESULTS AND DISCUSSION}

The figure 3.1 shows the evaporative cooler with two compartments and two evaporative media

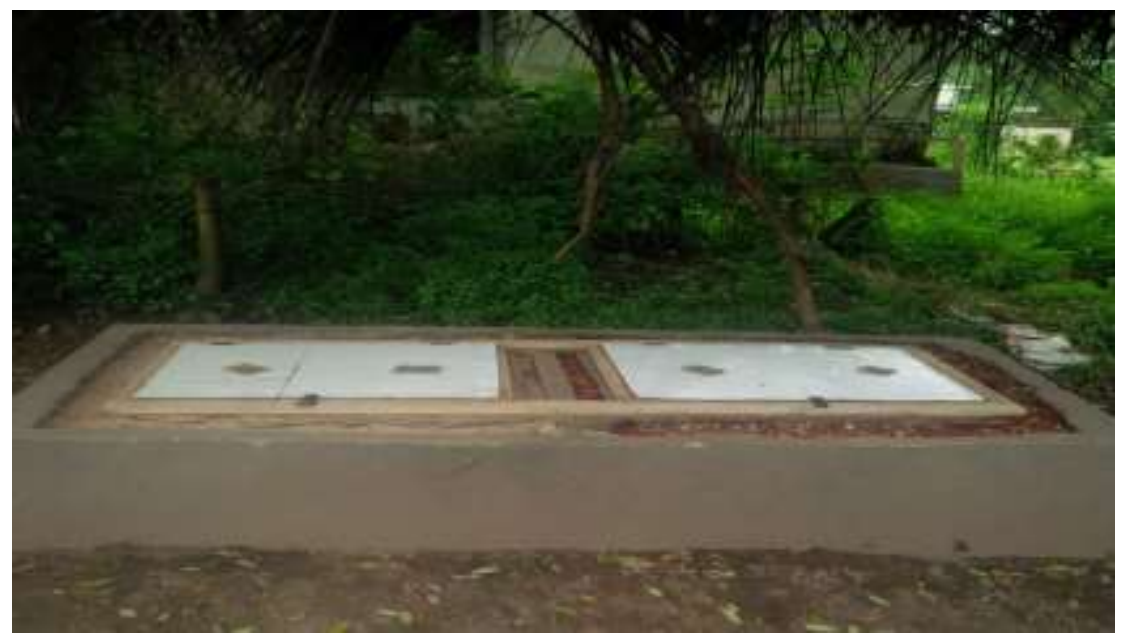

Figure 3.1. Evaporative cooler performance evaluation

Table 3.1. Shows the average daily temperatures of tomatoes stored in the evaporative cooler and under ambient conditions.

Table 3.1. Daily Average Temperature readings $\left({ }^{\circ} \mathrm{C}\right)$

\begin{tabular}{|c|c|c|c|c|c|c|c|c|c|}
\hline & TEM & $\overline{\text { ATUF }}$ & & & & & & & \\
\hline DAYS & 1 & 2 & 3 & 4 & 5 & 6 & 7 & 8 & 9 \\
\hline $\begin{array}{l}\text { Evaporative } \\
\text { cooler }\end{array}$ & 38.0 & 37.0 & 38.0 & 37.0 & 36.5 & 38.0 & 38.0 & 37.5 & 38.5 \\
\hline $\begin{array}{l}\text { Ambient } \\
\text { conditions }\end{array}$ & 39.5 & 39.5 & 38.5 & 37.5 & 38.5 & 38.5 & 39.0 & 39.5 & 37.0 \\
\hline
\end{tabular}

Table 3.2. Shows the average daily humidity values of tomatoes stored in the evaporative cooler and under ambient conditions.

Table 3.2. Daily Average Relative Humidity readings (\%)

\begin{tabular}{|c|c|c|c|c|c|c|c|c|c|}
\hline & HUM & & & & & & & & \\
\hline DAYS & 1 & 2 & 3 & 4 & 5 & 6 & 7 & 8 & 9 \\
\hline $\begin{array}{l}\text { Evaporative } \\
\text { cooler }\end{array}$ & 74.5 & 74.0 & 75.5 & 74.0 & 76.0 & 74.0 & 74.5 & 74.5 & 74 \\
\hline $\begin{array}{l}\text { Ambient } \\
\text { conditions }\end{array}$ & 73.0 & 73.5 & 73.5 & 71.5 & 74.0 & 73.5 & 73.0 & 73.0 & 71.5 \\
\hline
\end{tabular}


International Journal of Advances in Scientific Research and Engineering (ijasre), Vol 5 (9), September-2019

Table 3.3. Shows the average daily cooling efficiencies of the evaporative cooler and ambient storage.

Table 3.3. Daily Average Cooling Efficiency Calculations (\%)

\begin{tabular}{llllllllll}
\hline \multicolumn{1}{l}{ COOLING EFFICIENCY (\%) } \\
\hline $\begin{array}{l}\text { DAYS } \\
\begin{array}{l}\text { Evaporative } \\
\text { cooler }\end{array}\end{array}$ & 26.0 & 2 & 3 & 4 & 5 & 6 & 7 & 8 & 9 \\
$\begin{array}{l}\text { Ambient } \\
\text { conditions }\end{array}$ & 20.0 & 27.5 & 26.5 & 29.0 & 26.0 & 29.0 & 26.0 & 26.0 & 29.0 \\
\hline
\end{tabular}

Table 3.4. Shows the average weight readings of tomatoes stored in the evaporative cooler and under ambient conditions.

Table 3.4. Average weight readings (g)

\begin{tabular}{|c|c|c|c|c|c|c|}
\hline & WEIG & & & & & \\
\hline DAYS & 1nitial & 2 & 4 & 6 & 8 & 9 \\
\hline $\begin{array}{l}\text { Evaporative } \\
\text { cooler }\end{array}$ & 313.5 & 295.5 & 256.0 & 223.5 & 198.0 & 189.5 \\
\hline $\begin{array}{l}\text { Ambient } \\
\text { conditions }\end{array}$ & 344.0 & 315.0 & 272.5 & 229.0 & 186.0 & 167.5 \\
\hline
\end{tabular}

Table 3.5. Shows the changes in colour of tomatoes stored in the evaporative cooler and under ambient conditions.

Table 3.5 Colour Assessment of tomatoes during storage

\begin{tabular}{|c|c|c|c|c|c|c|c|c|c|}
\hline & \multicolumn{9}{|c|}{ FRUIT COLOUR } \\
\hline DAYS & 1 & 2 & 3 & 4 & 5 & 6 & 7 & 8 & 9 \\
\hline $\begin{array}{l}\text { Evaporative } \\
\text { cooler }\end{array}$ & Red & Red & Red & Red & Red & Red & Red & Red & Red \\
\hline $\begin{array}{l}\text { Ambient } \\
\text { conditions }\end{array}$ & Red & Red & $\begin{array}{l}\text { Reddish- } \\
\text { yellow }\end{array}$ & Yellow & $\begin{array}{l}\text { Brown- } \\
\text { Black }\end{array}$ & ---- & ---- & ---- & ---- \\
\hline
\end{tabular}

Table 3.6. Shows the fruit firmness of tomatoes stored in the evaporative cooler and under ambient conditions.

Table 3.6. Fruit firmness during storage

\begin{tabular}{|c|c|c|c|c|c|c|c|c|c|}
\hline & FRUI & IRMN & & & & & & & \\
\hline DAYS & 1 & 2 & 3 & 4 & 5 & 6 & 7 & 8 & 9 \\
\hline $\begin{array}{l}\text { Evaporative } \\
\text { cooler }\end{array}$ & $\begin{array}{l}\text { Very } \\
\text { firm }\end{array}$ & $\begin{array}{l}\text { Very } \\
\text { firm }\end{array}$ & Very firm & Firm & Firm & Firm & Soft & Soft & $\begin{array}{l}\text { Very } \\
\text { soft }\end{array}$ \\
\hline $\begin{array}{l}\text { Ambient } \\
\text { conditions }\end{array}$ & $\begin{array}{l}\text { Very } \\
\text { firm }\end{array}$ & Firm & Firm & Soft & Rotten & --- & ---- & ---- & ---- \\
\hline
\end{tabular}

Table 3.1 shows that the evaporative cooler had consistently lower temperature values than the ambient temperature during each day of storage. Table 3.2 shows relative humidity values of the evaporative cooler when compared with ambient values. The evaporative cooler had higher relative humidity values. This is consistent with evaporative cooling principles. Average cooling efficiency values for the evaporative cooling structure were consistently higher than those of ambient storage. This shows that fruit vegetables store better under evaporative cooling conditions than under ambient conditions.

Average weight readings show that tomatoes stored in the evaporative cooler lost weight slower than those stored under ambient conditions. This implies that tomatoes stored under evaporative cooling lost less moisture and can be sold for more profit by farmers. Tomatoes stored under ambient conditions showed significantly more marked colour changes. On the $3^{\text {rd }}$ day, the tomatoes changed from a reddish colour to yellow and later on to black. The tomatoes stored in the cooling chamber still retained 
their colour with little significant change within the test period, but spoilage of samples in the cooling chamber were noticed on the $6^{\text {th }}$ day of the test period.

The tomatoes stored in the cooling chamber still retained their firmness till the $6^{\text {th }}$ day but those stored under ambient temperature started to lose firmness after the $3^{\text {rd }}$ day and after the $6^{\text {th }}$ day most of the tomatoes had started rotting.

\subsection{Evaporative cooler cost analysis}

The evaporative facility cost a total of twenty-two thousand naira (N22, 000) which is quite affordable for local farmers. Factoring in labour (30\% of material cost), overhead (10\% of material cost) and a modest thirty percent profit margin gave the final selling price of the facility at thirty seven thousand, four hundred naira only (N37, 400).

\subsection{CONCLUSIONS AND RECOMMENDATIONS}

An Evaporative cooling chamber filled with river sand as absorbent material with application of water thrice a day performed better when compared to storing the tomatoes under ambient conditions. It is therefore recommended that porous storage media should be developed for the storage of tomatoes and other fruits and vegetables. Further studies on this work should vary the use of different absorbent materials in respect to availability, cost, and durability amongst others.

\section{REFERENCES}

1. Amrat I.B., Samuel D.V.K and Vimala B. (2013) Evaporative cooling system for storage of fruits and vegetables- a review Journal of Food Science and Technology 2013 Jun:50(3); 429- 442

2. Chandy K.T. (2016) Post harvest loss of fruit and vegetables. Booklet No 74, Post harvest techniques, Agricultural and Environmental Education, Accessed March 27, 2017

3. Ihekoronye A.I and Ngoddy P.O. (1985) Tropical fruits and vegetables. Integrated food science and technology for the Tropics. Macmillan Publishers; pp: 293-311.

4. Kinch R. (2016) Understanding the benefits of evaporative cooling. Accessed from Datacenter Dynamics 28th March 2017

5. Muhammad R.H, Hionu G.C and Olayemi F.F (2012): Assessment of the post-harvest knowledge of fruit and vegetable farmers in Garun Mallam L.G.A of Kano, Nigeria. International journal of Development and Sustainability, vol.1 No.2, pp. 510-515

6. Odesola I.F and Onyebuchi O. (2009) A review of porous evaporative cooling for the preservation of fruits and vegetables. The Pacific Journal of Science and Technology, Vol 10, No 2, November 2009, pp 935- 940

7. Olosunde W.A (2006) Performance evaluation of absorbent materials in the evaporative cooling system for the storage of fruits and vegetable. M.sc Thesis, Department of Agricultural Engineering, University of Ibadan, Ibadan.

8. Udayanga H.L., Weaeasinha S., Kannangara R.D., Ayaj A.M, Guruge Y.V., and Priyardarshani W.M (2015) Preliminary investigation on developing low cost evaporative cooling chamber. International Research Symposium on Engineering Advancements 2015 (RSEA 2015) saitm, Malabe, Sri lanka. pp 310-311. 